\title{
Major and trace element compositions of post-collisional, peraluminous Garam Chashma granite, Hindukush Range, northwestern Pakistan
}

\author{
Mohammad Zafar*, Mamoru Murata*, Tahseenullah Khan**, \\ Hiroaki OzawA* and Hiroshi NishimurA* \\ *Department of Geosciences, Faculty of Science, Naruto University of Education, Naruto, Tokushima 772-8502, Japan \\ **Geoscience Laboratory, Geological Survey of Pakistan, Islamabad, Pakistan
}

\begin{abstract}
The post-collisional Garam Chashma leucogranite with $\mathrm{K}-\mathrm{Ar}$ (biotite) ages of 20-18 Ma occurs in the Hindukush Range (Trans-Himalayas), northwestern Pakistan. The leucograntie is per-aluminous and shows a restricted range of $\mathrm{SiO}_{2}$ contents (72-75 wt\%). It is different, both in mineralogy and chemical characteristics, from the surrounding pre-collisional granodiorites and post-collisional meta-aluminous to per-aluminous Miocene Baltoro granite from Trans-Himalayas in Northeast Pakistan. The age and chemical trends of Garam Chashma leucogranite are similar to those of the Higher Himalayan granites of Pakistan, India, Nepal and South Tibet, suggesting similar source and/or processes of formation.
\end{abstract}

\section{Introduction}

Most of the post-collisional granites in the IndianNepal Himalayas occur in Higher Himalayas (collision zone) and Trans-Himalayas on the southern margin of the Asian plate. The westernmost extension of the Himalayas is situated in the northern Pakistan. The granitic activities in northern Pakistan are more complex than those in the Indian-Nepal Himalayas because of the presence of Kohistan-Ladakh island arc, squeezed between Asian and Indian plates (Fig. 1). The petrological investigations of post-collisional granitic rocks in the northwestern Pakistan would lead us to better understanding of the mountain building processes of Himalayas and adjacent terranes.

The study of per-aluminous (S-type) granitic rocks can help us to determine the $\mathrm{P}-\mathrm{T}$ conditions at the time of magma genesis using $\mathrm{Al}$-rich minerals such as garnet, cordierite, muscovite and biotite. The per-aluminous

M. Zafar, e9820107@ naruto-u.ac.jp

M. Murata, 村田 守, atarumm@ naruto-u.ac.jp Corresponding author

T. Khan, tahseen@ geolab.isb.sdnpk.org

H. Ozawa，小澤大成，hiroaki@ naruto-u.ac.jp

H. Nishimura，西村 宏，naruto.hiroshi.nishimura@ nifty.ne.jp granitic rocks of Higher Himalayas have been investigated by many authors (e.g. Le Fort, 1981; Searle et al., 1988 and 1997; Guillot and Le Fort, 1995; Inger and Harris, 1993). But, post-collisional granitic rocks of the Trans-Himalayas have not been studied in detail.

In Pakistan, post-collisional granites on the southern margin of the Asian plate (Trans-Himalayas) are scarcely distributed and are mostly in the form of small sills and dikes (Searle et al., 1988). Exceptionally, the Baltoro granite (Rex et al., 1988) to the northeast and Garam Chashma granite to the northwest are batholiths (Fig. 1). The Baltoro granitic rocks of $25.5-21.4 \mathrm{Ma}$ ( $\mathrm{U}-\mathrm{Pb}$ zircon) have been investigated by Parrish and Tirrul (1989) and Searle et al. (1992). On the other hand, the Garam Chashma leucogranite has not been studied in detail yet.

In this paper we present the major and trace element chemistry of the post-collisional Garam Chashma granite. A comparison with some pre- ${ }^{-}$and post-collisional granites from southern margin of the Asian plate and Higher Himalayas is also presented.

\section{Tectonics of the northern Pakistan}

The main tectonic units of the northern Pakistan include the Asian plate, Indian plate and the Kohistan-Ladakh 


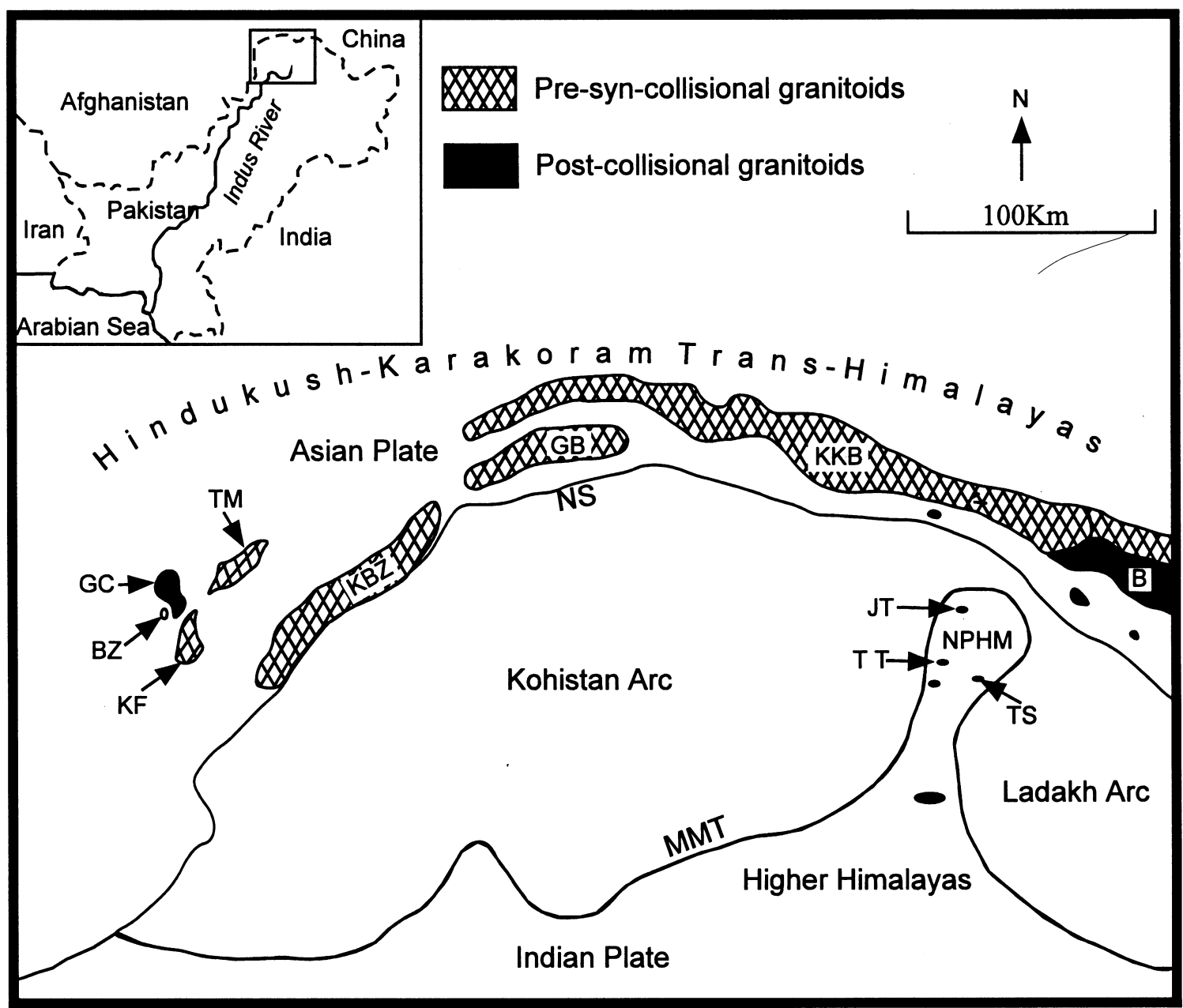

Figure 1. Geological sketch map of the northern Pakistan (after Pudsey, 1985; Hildebrand et al., 1998; Schneider et al, 1999a, b). Inset shows location of the map. NS, Northern Suture; MMT, Main Mantle Thrust; NPHM, Nanga Parbat-Haramosh Massif; KKB, Karakoram batholith; GB, Ghamu Bar; KBZ, Kesu Buni Zom; TM, Tirich Mir; KF, Kafiristan; BZ, Birzine; GC, Garam Chashma; B, Baltoro; JT, Jutial; TT, Tato; TS, Tarshing.

island arc. The Northern Suture (NS) bounds the island arc to the north and Main Mantle Thrust (MMT) to the south (Fig. 1). The Northern Suture was formed due to the closure of the back-arc around 102 to $75 \mathrm{Ma}$ (Petterson and Windley, 1985). The Main Mantle Thrust was developed when Indian plate collided with the Kohistan island arc in 55-40 Ma (Tahirkheli, 1982; Coward et al., 1986; Rowley, 1996).

The Kohistan arc was generated as a result of intraoceanic subduction during Cretaceous (Searle, 1991; Treloar and Izatt, 1993). The arc was then intruded by pre-collisional granitoids of $102 \mathrm{Ma}$ (Petterson and Windley, 1985). The intra-arc rifting and magmatism of about $40 \mathrm{Ma}$ resulted in the post-collisional calcalkaline Andean type batholiths (Khan et al., 1993).

The subduction of the Indian plate under the Kohistan arc and the Asian plate continued even after the collision resulting in thickening of the crust and
Barrovian type of metamorphism with its peak between 40 and $25 \mathrm{Ma}$ (Pudsey et al., 1985). This metamorphism episode was followed by the intrusions of leucogranites ranging in age from 28 to $12 \mathrm{Ma}$ (Le Fort et al., 1986).

The Nanga Parbat-Haramosh Massif (NPHM) represents the western most extension of the Higher Himalayas in Pakistan. The granitic rocks in the massif are fine to coarse-grained tourmaline two-mica leucogranites. Their $\mathrm{U}-\mathrm{Pb}$ (zircon and monazite) ages range from 19-1 Ma (Zeitler et al., 1993; Schneider et al., 1999a and b).

\section{Geologic setting}

The granitic rocks in the Garam Chashma area can be divided into pre-collisional Tirich Mir (TM), Kafiristan (KF) and Birzine (BZ) granodiorites and the post-col- 
lisional Garam Chashma granite (GC) (Leak et al., 1989). They occur in the overlying Hindukush metamorphic complex, northwestern Pakistan. The Hindukush metamorphic complex consists of slates, amphibolites, gneisses, quartzite, marbles, biotite-garnet schists, mica schists and graphitic schists (Pudsey et al., 1985; Leak et al., 1989). The metamorphic grade increases towards northwest. Migmatite intercalations in the gneisses are observed to the southwest, towards Afghanistan border. Because of the metamorphism, fossils for age determination are not available in this area. The fossils found in the northwestern unit suggest Jurassic to Devonian age for all the rock units exposed in this area (Pasco, 1923; Calkins et al., 1981; Tahirkheli, 1982; Pudsey et al., 1985).

The pre-collisional Tirich Mir and Kafiristan granitic rocks are composed mainly of hornblendebiotite granodiorites with $\mathrm{K}$-feldspar megacrysts ranging in size from millimeters to a few centimeters. These are strongly foliated and are sometimes described as granodiorite gneisses (Khan, 1986). Tirich Mir granitic rocks are characterized by the presence of quartz and $\mathrm{K}-$ feldspar augens. The Tirich Mir pluton yields $117 \pm 5$ $\mathrm{Ma} \mathrm{Rb-Sr} \mathrm{(biotite)} \mathrm{age} \mathrm{(Desio} \mathrm{et} \mathrm{al.,} \mathrm{1964),} \mathrm{whereas,}$ Kafiristan pluton gives $48 \pm 2 \mathrm{Ma} \mathrm{K}$-Ar (biotite) age (Searle, 1991). The $48 \pm 2 \mathrm{Ma}$ age of the Kafiristan pluton may be an erroneous result, because field studies show strong deformation and effects of metamorphism suggesting its intrusion before the formation of the Northern Suture.

The Birzine granodiorite is exposed to the southwest of Garam Chashma. It occurs within the migmatite zone and is fine to medium-grained granodiorite. Biotite and hornblende sometimes show preferred orientation.

The post-collisional Garam Chashma pluton is located about $30 \mathrm{~km}$ northwest of Northern Suture and covers an area of about $300 \mathrm{~km}^{2}$. It is composed of fine to coarse-grained homogeneous leucogranite. The granite intrudes into the Hindukush metasediments and yields $\mathrm{K}-\mathrm{Ar}$ (biotite) ages of $20-18 \mathrm{Ma}$ (Zafar et al., 2000). A U-Pb (monazite) isotope age of $24 \pm 0.5 \mathrm{Ma}$ is also reported by Hildebrand et al. (1998). Moderate foliation usually marked by muscovite and biotite can be observed near the contacts of intrusion. Major rock forming minerals include quartz, plagioclase, $\mathrm{K}$-feldspar, muscovite and biotite with subordinate garnet and tourmaline. Aplitic and pegmatitic veins and/or dikes are ubiquitous in the pluton.

The Nanga Parbat-Haramosh Massif, a tectonic half window, is the westernmost extension of the Himalayan mountain chain in northern Pakistan
(Schneider et al., 1999a). It is composed of Precambrian basement, consisting of gneisses, schists and interbedded amphibolites (Chamberlain et al., 1995). The basement rocks are intruded by numerous granitic stocks and dikes, ranging in age from 19 to $1 \mathrm{Ma}$ (Zeitler et al, 1993; Chamberlain et al., 1995; Schneider et al., 1999a and b). The Jutial pluton (JT), located in the northern part of the massif, is composed of two-mica tourmaline granite with a $\mathrm{U}-\mathrm{Th}-\mathrm{Pb}$ (zircon and monazite) age of 9.5 Ma (Schneider et al., 1999a). A fine to coarsegrained garnet tourmaline two-mica Tarshing granite (TS) intrudes into the Rupal Shear zone. The Tato pluton (TT), exposed to the north of Nanga Parbat Mountain, is composed of tourmaline two-mica granite. It gives a U-Pb zircon age of $1 \mathrm{Ma}$ (Zeitler et al., 1993).

\section{Petrography}

\section{Tirich Mir, Kafiristan and Birzine granodiorites}

The Tirich Mir pluton is composed of hornblende biotite granodiorite and biotite granite. Biotite is brown in color and shows strong preferred orientation. Some biotites are bent, sheared and broken into pieces. Laths of biotite surround subhedral to euhedral plagioclase and $\mathrm{K}$-feldspar. Plagioclase crystals are occasionally zoned and contain inclusions of fine-grained biotite and quartz.

The Kafiristan pluton is composed of hornblende biotite granodiorite and biotite granite. Biotite is greenish brown in color and usually shows preferred orientation. Bent, sheared and fractured biotites are also observed. Graphic intergrowths of plagioclase and quartz are observed.

The Birzine pluton is composed of hornblende biotite granodiorite. Hornblende crystals are green in color and euhedral in shape. Biotite shows dark brown color. Bent, sheared and fractured biotites are usually observed.

\section{Garam Chashma granite}

The Garam Chashma pluton is composed of fine to coarse-grained two-mica leucogranite. The granite is homogeneous and is characterized by the absence of lithofacies variation. The rocks are composed of muscovite, biotite, plagioclase, $\mathrm{K}$-feldspar and quartz with subordinate garnet and tourmaline. The muscovite is evenly distributed, whilst the ratio of biotite to muscovite is not constant. Muscovite is also found as inclusions in plagioclase and $\mathrm{K}$-feldspar. Muscovite and biotite clots surrounded by plagioclase and $\mathrm{K}$-feld- 
spar are also observed. Biotite is brown in color and contains inclusions of zircon and/or sillimanite. Plagioclase is euhedral to subhedral and occasionally contains inclusions of muscovite, biotite and zircon. $\mathrm{K}$-feldspar is usually euhedral to subhedral containing abundant inclusions of muscovite, biotite, and zircon. Perthitic and micrographic intergrowths of $\mathrm{K}$-feldspar and quartz are also observed. Quartz crystals are usually interstitial to the plagioclase and K-feldspar. Subhedral to euhedral almandine garnet crystals are usually fractured. The skeletal frameworks of garnet and quartz are observed, but no reaction rim of garnet is observed. Zircon inclusions are present in garnets. A few scattered anhedral greenish crystals of tourmaline are also observed. It shows light to dark green optical zonation and is devoid of any inclusions. Among the accessory minerals apatite is the most abundant. Other accessory minerals include zircon, sillimanite and allanite. Pyrrohotite can be observed in a few thin sections.

\section{Nanga Parbat Haramosh Massif}

The Jutial, Tarshing and Tato plutons are composed of massive to slightly deformed, fine to coarse-grained tourmaline two-mica leucogranites. Garnet is absent in Jutial granite, whereas in Tarshing and Tato granites it is usually restricted to the biotite abundant lithofacies. The Tato granite is rich in tourmaline as compared to the other two granites. In all the three granites, biotite is usually subhedral, brown in color and rarely contains inclusions of zircon and/or monazite. Plagioclase shows zoning and contains inclusions of muscovite and biotite. Tourmaline is pale-green and sometimes shows zoning and contains inclusions of quartz and plagioclase. The accessory minerals include apatite, cordierite, zircon, monazite and garnet. Garnet is euhedral to subhedral and occasionally contains inclusions of quartz, muscovite and biotite. Accessory zircon and monazite mostly occur as inclusions in plagioclase and $\mathrm{K}$-feldspar.

\section{Major and trace components}

The powdered samples were analyzed for major and trace elements ( $\mathrm{Ce}, \mathrm{Cr}, \mathrm{Nb}, \mathrm{Ni}, \mathrm{Pb}, \mathrm{Sr}, \mathrm{Th}, \mathrm{Y}, \mathrm{Zr}$ and $\mathrm{Ba}$ ) at the Naruto University of Education, using a wavelength despersive X-ray fluorescence spectrometer (Rigaku RIX 2000). Glass beads, from finely ground samples, were prepared with sample to flux ratio of $1: 10$ and analyzed for major elements using fundamental parameter method, whereas trace elements were deter- mined using pure press pellets and the empirical calibration curve method (Murata, 1993). The major element data were recalculated to 100 percent. The results of major and trace elements of some representative samples are given in Table 1 .

\section{Tirich Mir, Kafiristan and Birzine granodiorites}

The $\mathrm{SiO}_{2}$ contents of Tirich Mir and Kafiristan granitic rocks range from 65 to $74 \mathrm{wt} \%$ and from 64 to $76 \mathrm{wt} \%$, respectively. The aluminum saturation index (ASI $=$ molar $\mathrm{Al}_{2} \mathrm{O}_{3} /\left[\mathrm{CaO}+\mathrm{Na}_{2} \mathrm{O}+\mathrm{K}_{2} \mathrm{O}\right]$ ) ranges between 0.92 and 1.16 , representing their metaluminous to peraluminous character. Irrespective of their similar $\mathrm{SiO}_{2}$ ranges, both rocks show different chemical trends on the $\mathrm{SiO}_{2}$ vs. $\mathrm{Al}_{2} \mathrm{O}_{3}$ and $\mathrm{SiO}_{2}$ vs. $\mathrm{Fe}_{2} \mathrm{O}_{3}$ plots (Figs. 2a and b). Only two analyzed samples of Birzine granodiorites show a possible extension of the chemical trend described for Tirich Mir granitic rocks. All the three precollisional granitic rocks of this area plot in the volcanic arc granite (VAG) field of the trace element discrimination diagrams (Figs. 2c and d) of Pearce et al. (1984).

\section{Garam Chashma granite}

The Garam Chashma granite shows a narrow $\mathrm{SiO}_{2}$ range, 72 to $75 \mathrm{wt} \%$ (Table 1). The aluminum saturation index (ASI) ranges from 1.03 to 1.25 , thereby representing its peraluminous character (Table 1). The $\mathrm{K}_{2} \mathrm{O} / \mathrm{Na}_{2} \mathrm{O}$ is also higher than 1.0.

\section{Nanga Parbat Haramosh Massif}

The major and trace element characteristics of the three leucogranites from the Nanga Parbat Haramosh Massif are similar to those of the Garam Chashma granite. They also show a narrow $\mathrm{SiO}_{2}$ range (73-77 wt\%) and $\mathrm{K}_{2} \mathrm{O} / \mathrm{Na}_{2} \mathrm{O}$ ratios higher than 1.0. The aluminum saturation index varies from 1.01 to 1.35 , showing their peraluminous nature (Table 1).

\section{Discussion}

In this section we make a comparison of Garam Chashma leucogranite with post-collisional plutons from the Trans- and Higher Himalayas.

\section{Comparison with Trans-Himalayan Baltoro granite}

The Baltoro pluton is located in the Karakoram Range on southern margin of the Asian plate, northeastern Pakistan (Fig. 1). The 25.5-21.4 Ma (U-Pb zircon) age 


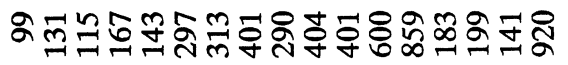

rananNmnomonabtro

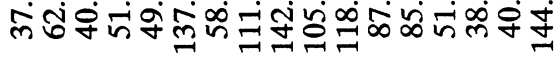
otmagrmotnogaOnmn

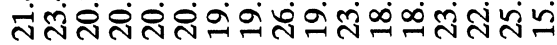
N.ท유.

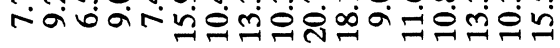

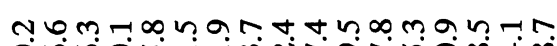

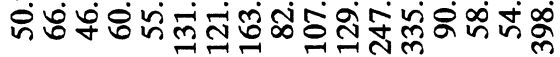

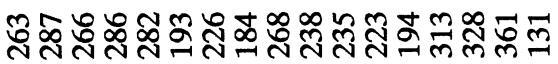

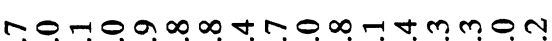

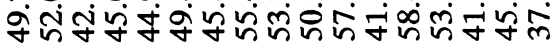

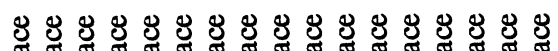

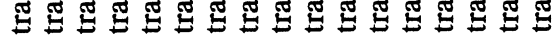

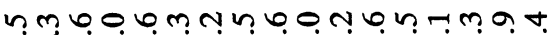

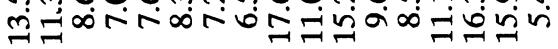

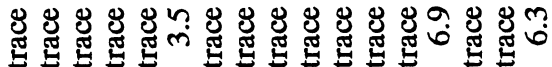
om

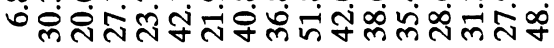

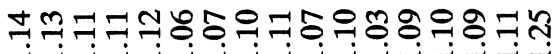

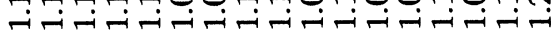

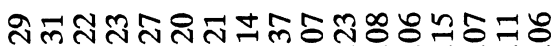
00000000000000000

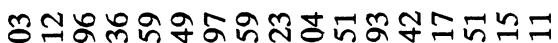

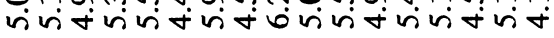

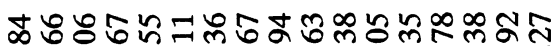
लिं में

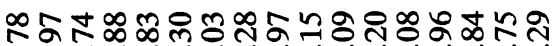

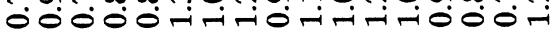

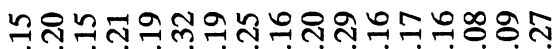

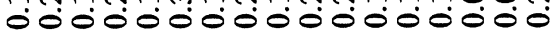
ธํํํํํํํํํํํํํํํํํํํำ

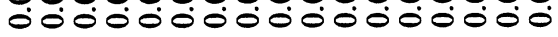

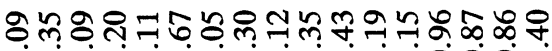
ir

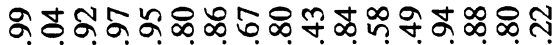

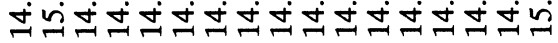

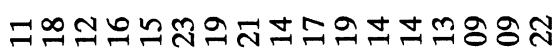

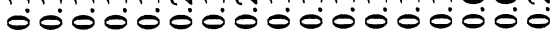

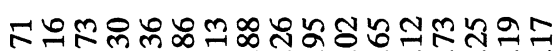

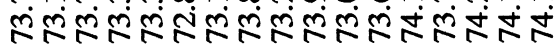

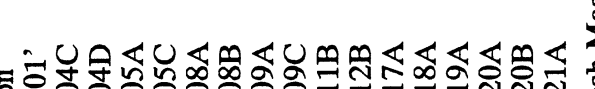

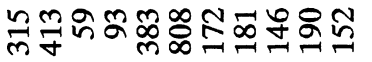

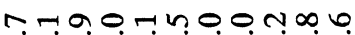

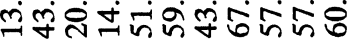

$\infty n-m b a \infty m+n n$ ล் $\infty m \pi n \infty N-n N$

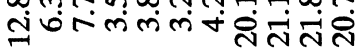

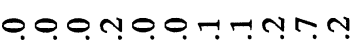

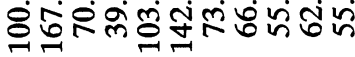

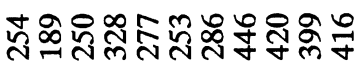

no.

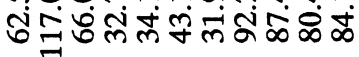
\& \& \& \&

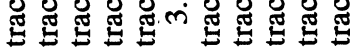

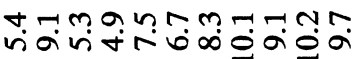

\& onNmoro-nNo

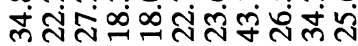

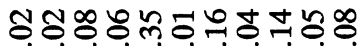

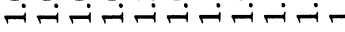

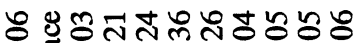

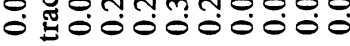

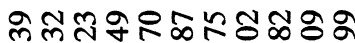

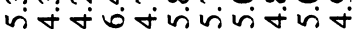

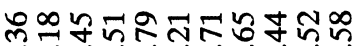

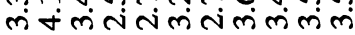

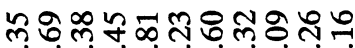
-

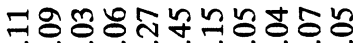

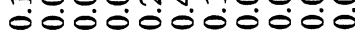

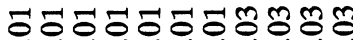

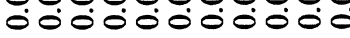

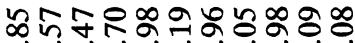

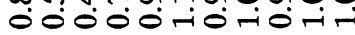

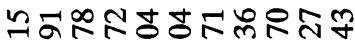

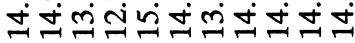
ㅋㅇ육의옹ㅇㅇㅇ ல0்0000000்

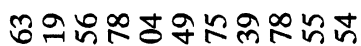

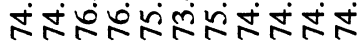
岁

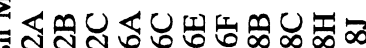

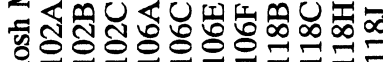

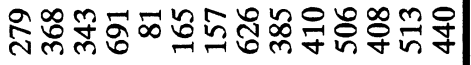
Nno an

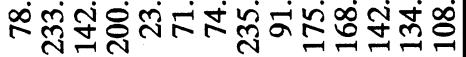
nN-G

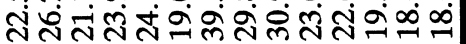
NoNm+NonTmovol అ่ ๓

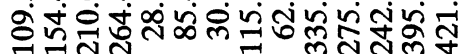

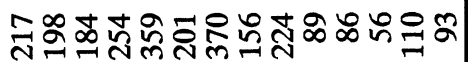
mกNmกMNN-OMNO-

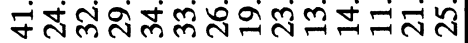

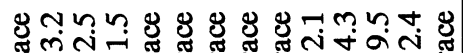

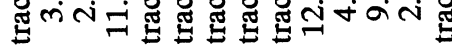

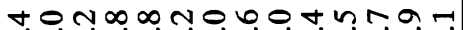

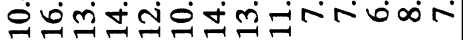

OUतก \& \& \&

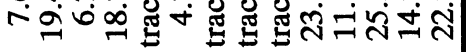
r ma

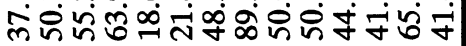

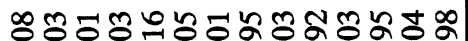

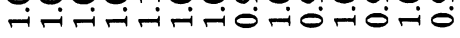

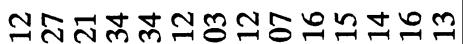

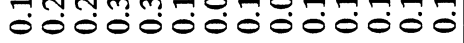

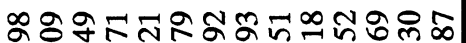

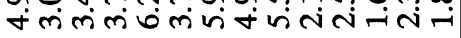

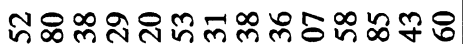
लें

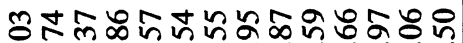

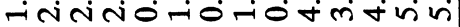

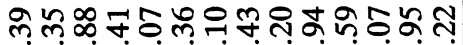

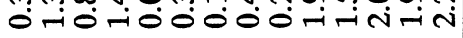

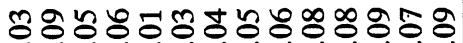

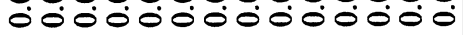

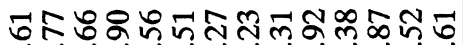

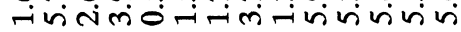

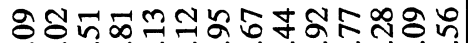

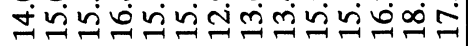

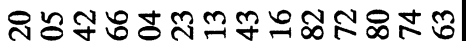

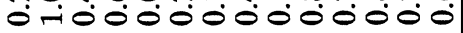

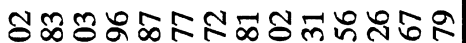

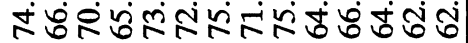

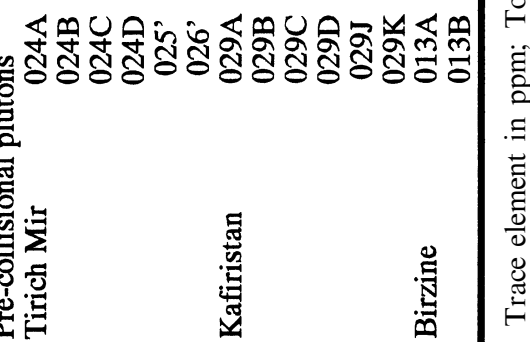



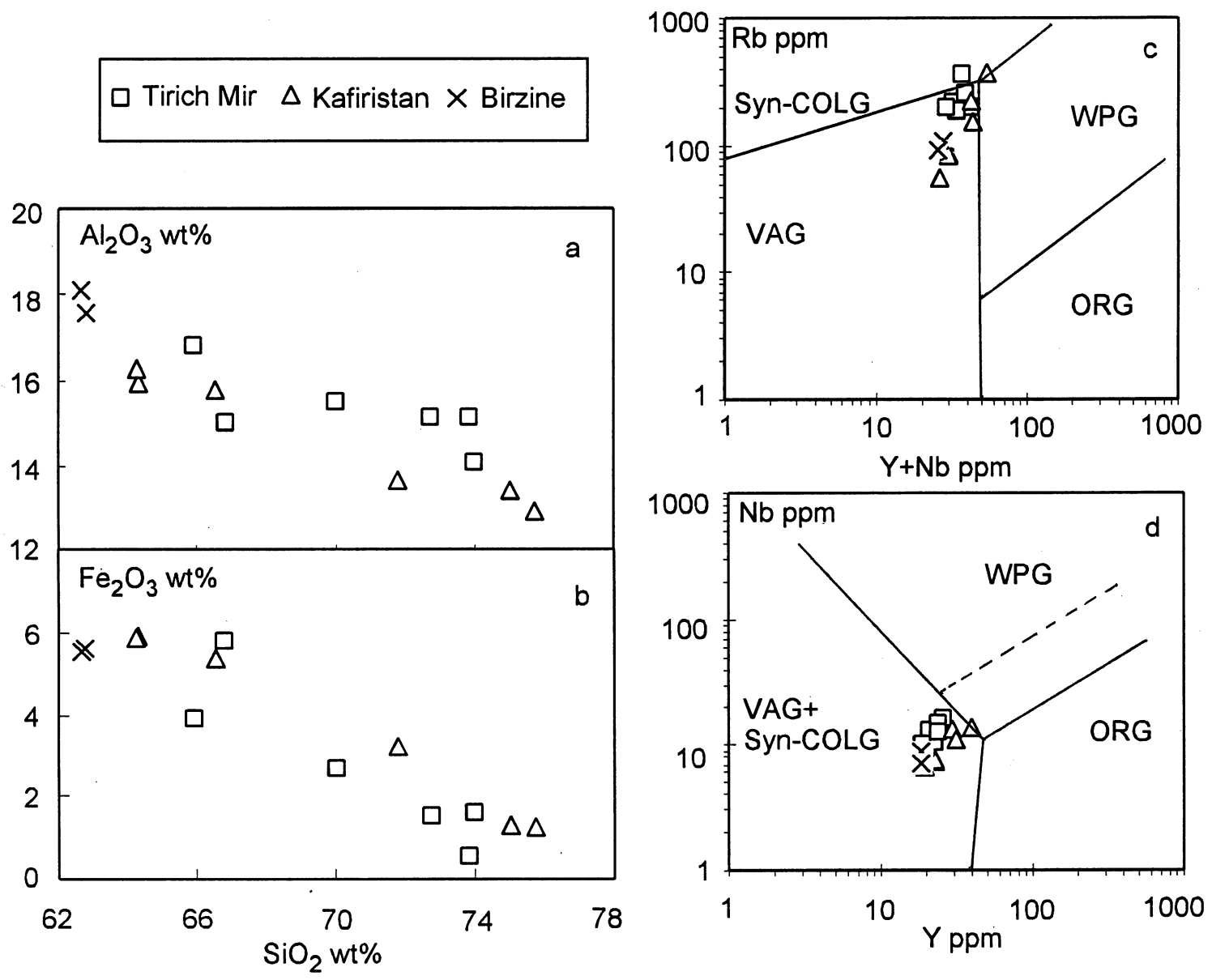

Figure 2. Representative major elements versus $\mathrm{SiO}_{2}(\mathrm{a}, \mathrm{b})$ and trace element discrimination plots (c, d) of the pre-collisional granodiorites from the Garam Chashma area.

Syn-COLG, Syn-collision granites; VAG, volcanic arc granites; WPG, within plate granites; ORG, ocean ridge granites.

has been assigned to this pluton (Parrish and Tirrul, 1989). The Baltoro pluton has been lithologically divided into monzogranite and leucogranite lithofacies. These rocks are metaluminous to peraluminous (ASI $=$ 0.90-1.14) and their $\mathrm{SiO}_{2}$ range lies between 67 and 77 wt\% (Searle, 1991). Some major and trace element plots of representative samples are shown in Fig. 3. Detailed compositional diagrams can be seen in Murata et al. (1999). These plots are depicting linear trends suggesting that the monzograntic part is the least evolved one and acted as a parent magma to generate the leucogranitic part by fractional crystallization (Searle et al., 1992).

The Garam Chashma granite has a restricted $\mathrm{SiO}_{2}$ range as compared to the Baltoro granitic rocks. It has higher $\mathrm{Al}_{2} \mathrm{O}_{3}, \mathrm{~K}_{2} \mathrm{O}$ and $\mathrm{Y}$ contents and lower $\mathrm{Na}_{2} \mathrm{O}$ content than the Baltoro granite (Fig. 3). We conclude that the Garam Chashma granite is different from the Baltoro granite in mineral assemblage and chemistry.

\section{Comparison with Higher Himalayan granites}

As the Garam Chashma granite is considered to be different from the post-collisional Baltoro granite of the eastern Karakoram Range in Pakistan, we attempt to compare it with post-collisional Higher Himalayan granites from Pakistan, India, Nepal and South Tibet.

The Nanga Parbat-Haramosh Massif is the westernmost extension of the Higher Himalayas in northern Pakistan (Schneider et al., 1999a). The Jutial, Tarshing and Tato plutons of the massif are tourmaline two-mica leucogranites. All three leucogranites are characterized by a restricted $\mathrm{SiO}_{2}$ range (73-77 wt\%, Table 1) and the absence of lithofacies variation. Their major element variation plots (Fig. 4) show similar trends to the Garam Chashma ones. On the basis of mineralogical and chemical data, we conclude that the Higher Himalayan granites from northern Pakistan resemble to the Garam Chashma granite.

The Miocene Higher Himalayan granitic rocks are 

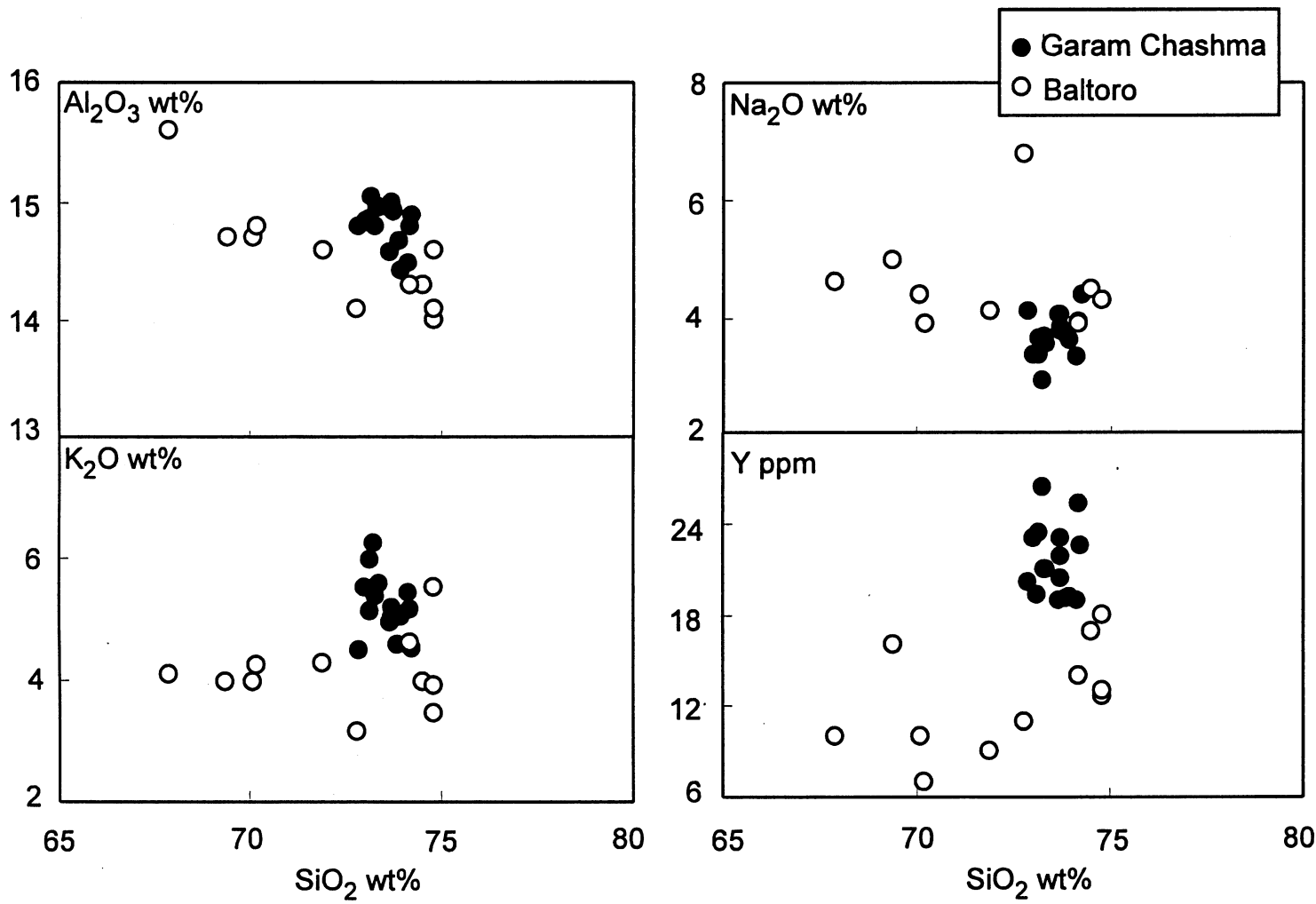

Figure 3. Representative major and trace elements versus $\mathrm{SiO}_{2}$ plots of the post-collisional granitic rocks from the Asian Plate, northern Pakistan.
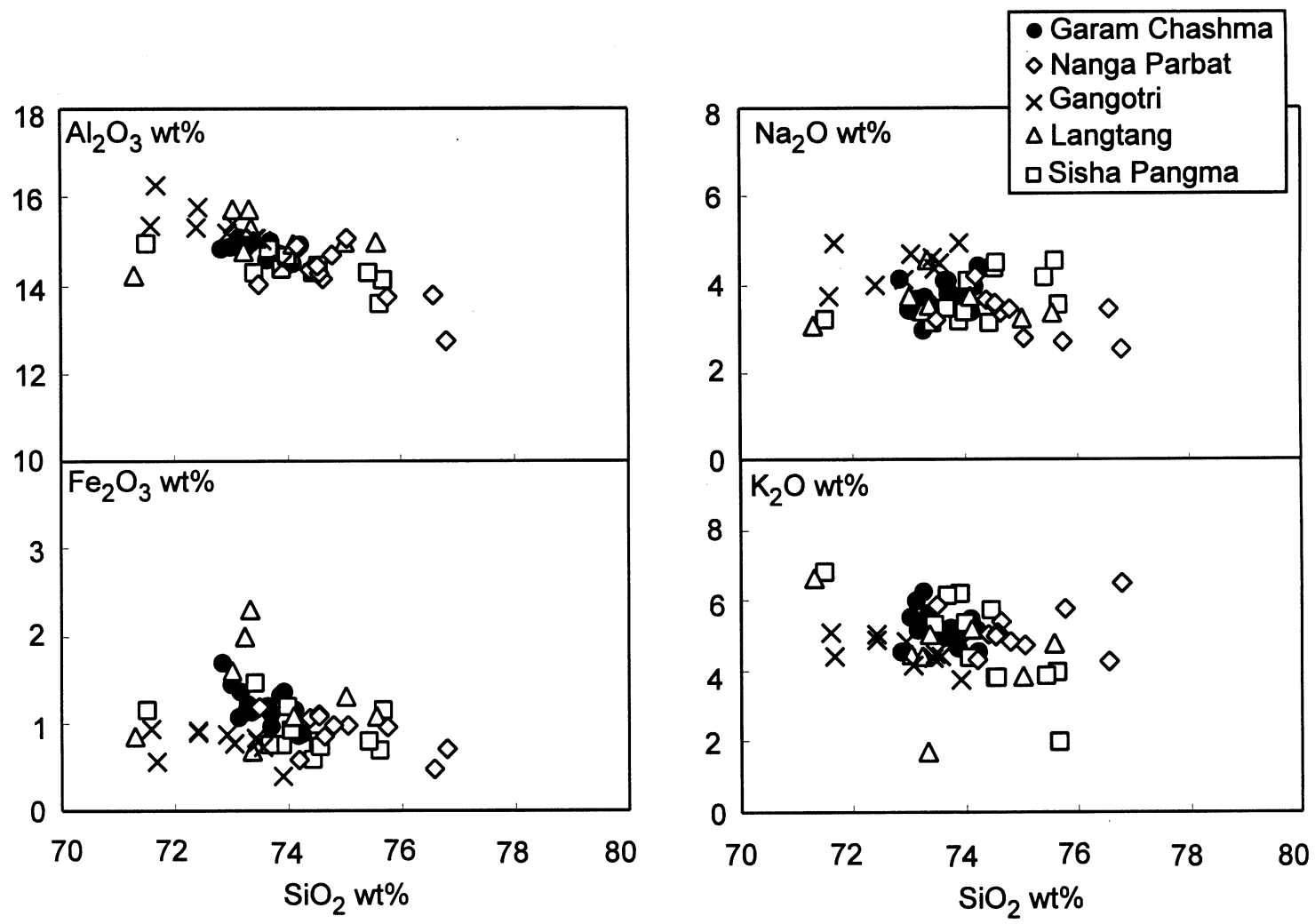

Figure 4. Representative major and trace elements versus $\mathrm{SiO}_{2}$ plots of the post-collisional granitic rocks from Garam Chashma and Higher Himalayas of Pakistan, Indian, Nepal and South Tibet. 
ubiquitously distributed in India, Nepal, Bhutan and South Tibet. However, only a few of them have been thoroughly studied. Also their data published are inadequate and variable. We have selected three Higher Himalayan granites that have been studied relatively in detail. These include Gangotri pluton from India (Scaillet et al., 1990), Langtang pluton from Nepal (Inger and Harris, 1993) and Shisha Pangma pluton from South Tibet (Searle et al., 1997). These plutons are composed of tourmaline two-mica leucogranites. The radiometric ages of the Gangotri pluton range from 21 to $18 \mathrm{Ma}$ (Stern et al., 1989), whereas Shisha Pangma pluton yields 20-17 Ma ages (Searle et al., 1997). Their representative major elements versus $\mathrm{SiO}_{2}$ plots (Fig. 4) depict similar trends to those of the Garam Chashma and Nanga Parbat Haramosh Massif granites. However, $\mathrm{Fe}_{2} \mathrm{O}_{3}$ contents of Gangotri granite are slightly lower than those of the Garam Chashma and other Higher Himalayan granites. The similar age, mineral assemblage and chemical trends reveal that the Garam Chashma granite resembles to Higher Himalayan leucogranites.

\section{Conclusions}

The Garam Chashma leucogranite is located in the Hindukush Range (Trans-Himalayas) on the southern margin of the Asian plate. It differs in age, mineral assemblage and chemistry from the surrounding precollisional granitoids (Tirich Mir, Kafiristan and Birzine) and post-collisional Baltoro granite in the eastern Karakoram Range. However, it resembles to the Higher Himalayan granites from Pakistan, India, Nepal and South Tibet. From the aforementioned data we infer that the Garam Chashma granite was probably developed from the similar source and/or processes of evolution as those of the Higher Himalayan granites. The oxygen isotopes of the Garam Chashma rocks will appear in another paper to discuss its source.

\section{Acknowledgments}

One of the authors (M. Zafar) is thankful to Ministry of Education, Japan, for providing him an opportunity to work at the Naruto University of Education. We are also indebted to Mr. S.H. Gauhar, Director General, Geological Survey of Pakistan, for his continuous support. The manuscript was improved by valuable reviews and comments of Profs. S. Arai and S. Harayama.

\section{References}

Calkins, J.A., Jamiluddin, S., Bhuyan, K. and Hussain, A. (1981) Geology and mineral resources of the ChitralPartsan area, Hindukush Range, northern Pakistan. United States Geological Survey, Professional Paper, 716, G1-G33.

Chamberlain, C.P., Zeitler, P.K., Barnett, D.E., Winslow, D., Poulson, S.R., Leahy, T. and Hammer, J.A. (1995) Active hydrothermal systems during the recent uplift of Nanga Parbat, Pakistan Himalaya. Journal of Geophysical Research, 100, 439-453.

Coward, M.P., Windley, B.F., Broughton, R.D., Luff, I.W., Petterson, M.G., Pudsey, C.J., Rex, D.C. and Khan, M.A. (1986) Collision tectonics in the NW Himalayas. In Collision Tectonics (Coward, M.P. and Ries, A.C. Eds.). Geological Society of London, Special Publication, 19, 203-219.

Desio, A., Tongeorgi, E. and Ferrara, G. (1964) On the geological ages of some granites of the Karakoram-Hindukush and Badakhshan (Central Asia). 22nd International Geological Congress, New Delhi, 11, 479-496.

Guillot, S. and Le Fort, P. (1995) Geochemical constraints on the bimodal origin of High Himalayan leucogranites. Lithos, 35, 221-234.

Hildebrand, P.R., Noble, S.R., Searle, M.P., Parrish, R.R. and Shakirullah (1998) The tectonic significance of $24 \mathrm{Ma}$ crustal melting in the eastern Hindukush, Pakistan. Geology, 26, 871-874.

Inger, S. and Harris, N. (1993) Geochemical constraints on Leucogranite Magmatism in the Langtang Valley, Nepal Himalaya. Journal of Petrology, 34, 345-368.

Khan, M.A., Jan, M.Q. and Weaver, B.L. (1993) Evolution of the lower arc crust in Kohistan, N. Pakistan: temporal arc magmatism through early, mature and intra-arc rift stages. In Himalayan tectonics (Treloar P.J. and Searle M.P. Eds.). Geological Society of London Special Publication, 74, 123-138.

Khan, T. (1986) Geology of the pegmatite belt in Chitral, Northwest Frontier Province Pakistan. Geological Survey of Pakistan, Information Release, 266, 1-16.

Leak, R.C., Flecher, C.N.J., Haslam, H.W., Khan, B. and Shakirullah (1989) The origin and tectonic setting of strata bound tungsten mineralization within the Hindukush of Pakistan. Journal of Geological Society of London, 146, 1003-1016.

Le Fort, P. (1981) Manaslu leucogranite: a collision signature of the Himalaya, a model for its genesis and emplacement. Journal of Geophysical Research, 86, 10545-10568.

Le Fort, P., Debon, F., Pecher, A., Sonet, J. and Vidal, P. (1986) The $500 \mathrm{Ma}$ magmatic event in Alpine southern Asia, a thermal episode at Gondwana scale. In Evolution des Domaines Orogeniques d' Asie Meridionale (LeFort P. Ed.). Science Terre Memoir, 47, 191-209.

Murata, M. (1993) Major and trace component analysis of Korean Institute of Energy and Resources igneous rock reference samples using $\mathrm{X}$-ray fluorescence spectrometer. Research Bulletin of Natural Sciences, Naruto University of Education, 8, 37-49.

Murata, M., Zafar, M., Khan, T., Ozawa, H., and Nishimura, H. 
(1999) Major and trace element composition of postcollisional granitic rocks on the southern margin of Asian plate, North Pakistan. Research Bulletin of Natural Sciences, Naruto University of Education, 14, 15-28.

Parrish, R.R and Tirrul, R. (1989) U-Pb age of the Baltoro granite, northwest Himalaya, and implication for zircon inheritance and monazite $\mathrm{U}-\mathrm{Pb}$ systematic. Geology, 17, 76-1079.

Pasco, E.H. (1923) General report for the year 1922. pp. 51. Geological Survey of India Record.

Pearce, J.A., Harris, N.B.W. and Tindle, A.G. (1984) Trace Element Discrimination Diagrams for the Tectonic Interpretation of Granitic Rocks. Journal of Petrology, 25, 956-983.

Petterson, M.G. and Windley, B.F. (1985) Rb-Sr dating of the Kohistan arc batholith in the Trans-Himalaya of N. Pakistan and tectonic implications. Earth and Planetary Science Letters, 74, 45-57.

Pudsey, C.J., Coward, M.P., Luff, I.W., Shackleton, R.M., Windley, B.F. and Jan, M.Q. (1985) Collision zone between the Kohistan arc and the Asian plate in NW Pakistan. Transactions of the Royal Society of Edinburgh, Earth Sciences, 76, 463-479.

Rex, A.J., Searle, M.P., Tirrul, R., Crawford, M.B., Prior, D.J., Rex, D.C. and Barnicoat A. (1988) The geochemical and tectonic evolution of the central Karakoram, North Pakistan. Philosophical Transactions of the Royal Society of London, A326, 229-255.

Rowley, D.B. (1996) Age of initiation of collision between India and Asia: A review of stratigraphic data. Earth and Planetary Science Letters, 145, 1-13.

Scaillet, B., France-Lanord, C. and Le Fort, P. (1990) Badrinath-Gangotri plutons (Garhwal, India): petrological and geochemical evidence for fractionation processes in a high Himalayan leucogranite. Journal of Volcanology and Geothermal Research, 44, 163-188.

Schneider, D.A., Edwards, M.A., Zeitler, P.K. and Coath, C.D. (1999a) Mazeno Pass Pluton and Jutial Pluton, Pakistan Himalaya: age and implications for entrapment mechanisms of two granites in the Himalaya. Contributions to Mineralogy and Petrology, 136, 273-284.

Schneider, D.A., Edwards, M.A., Kidd, W.S.F., Zeitler, P.K. and Coath, C.D. (1999b) Early Miocene anatexis identified in the western syntaxis, Pakistan Himalaya. Earth and Planetary Science Letters, 167, 121-129.

Searle, M.P. (1991) Geology and tectonics of the Karakoram Mountain. pp. 358. J. Wiley and sons, New York.

Searle, M.P., Crawford, M.B., Rex, A.J. and Tirrul, R. (1992) Field relations, geochemistry, origin and emplacement of the Baltoro granite, Central Karakoram. Transactions of Royal Society of Edinburgh, Earth Sciences, 83, 519-538.

Searle, M.P., Rex, A.J., Tirrul, R., Rex, D.C. and Barnicoat, A. (1988) Metamorphic, magmatic and tectonic evolution of the Central Karakoram in the Biafo-Baltoro-Hush regions of N-western Himalaya. Geological Society of America, Special Paper, 232, 47-73.

Searle, M.P., Parish, R.R., Hodges, K.V., Harford, A., Ayers, M.W. and Whitehouse, M.J. (1997) Shisha Pangma leucogranite, South Tibetan Himalaya: field relations, geochemistry, age, origin and emplacement. Journal of Geology, 105, 295-317.

Stern, C.R., Kligfield, R. and Schelling, D. (1989) The Bhagirathi leucogranite of the High Himalaya (Garhwal, India); Age, petrogenesis, and tectonic implications. Geological Society of America, Special Paper, 232, 33-44.

Tahirkheli, R.A.K. (1982) Geology of the Himalaya, Karakoram and Hindukush in Pakistan. Geological Bulletin, University of Peshawar, 15, 1-51.

Treloar, P.J. and Izatt, C.N. (1993) Tectonics of the Himalayan collision zone between the Indian plate and the Afghan block: a synthesis. In Himalayan tectonics (Treloar P.J. and Searle M.P. Eds.). Geological Society of London, Special Publication, 74, 69-87.

Zafar, M., Murata, M., Khan, T., Ozawa, H. and Nishimura, H. (2000) K-Ar biotite ages from Miocene post-collisional Garam Chashma leucogranite, eastern Hindukush Range (Trans-Himalayas), northwestern Pakistan. Journal of Mineralogical and Petrological Sciences, 95, 101-106.

Zeitler, P.K., Chamberlain, C.P. and Smith, H.A. (1993) Synchronous anatexis, metamorphism, and rapid denudation at Nanga Parbat (Pakistan Himalaya). Geology, 21, $347-350$.

Manuscript received; 17 March, 2000

Manuscript accepted; 30 October, 2000 